\title{
Phenotypic and genotypic study of carbapenem-resistant Pseudomonas aeruginosa strains isolated from hospitalized patients
}

\section{Studiu fenotipic și genotipic la tulpinile de Pseudomonas aeruginosa izolate de la pacienți spitalizați}

\author{
Luminița Matroș ${ }^{1, *}$, Tibor Ludovic Krausz ${ }^{2}$, Stanca Lucia Pandrea ${ }^{1,3}$, Monica \\ Ioana Ciontea ${ }^{3}$, Erica Chiorean ${ }^{3}$, Lia Sorina Pepelea ${ }^{1}$, Antonela Marcela Berar ${ }^{4}$, \\ Lia Monica Junie ${ }^{1}$
}

${ }^{1}$ Department of Microbiology, Iuliu Hatieganu University of Medicine and Pharmacy, Cluj-Napoca, Romania, ${ }^{2}$ Molecular Diagnostic Laboratory, Public Health Department, Miercurea-Ciuc, Romania, Department of Microbiology, Iuliu Hatieganu University of Medicine and Pharmacy,

${ }^{3}$ Department of Microbiology, Medical Analysis Laboratory, Regional Institute of Gastroenterology and Hepatology "Prof. Dr. O. Fodor", Cluj-Napoca, Romania,

${ }^{4}$ Department of Prosthodontics, Faculty of Dentistry, Iuliu Hatieganu University of Medicine and Pharmacy, Cluj-Napoca, Romania

\begin{abstract}
Introduction: Nosocomial infections caused by Pseudomonas aeruginosa producing carbapenemases represent an important cause of morbidity and mortality among immunosuppressed patients. The aim of our study was to detect the production of metallo-carbapenemases (MBLs) by phenotypic methods and to detect the presence of the MBLs encoding genes (blaIMP and blaVIM) by PCR in P. aeruginosa strains isolated from hospitalized patients to the Regional Institute of Gastroenterology and Hepatology, Cluj-Napoca.

Material and methods: Between September 2014-February 2015, we tested thirty-eight P. aeruginosa strains resistant to carbapenems according to CLSI 2014 breakpoints, determined by Vitek ${ }^{\circledR}$ (BioMérieux), isolated from various clinical specimens. Phenotypic detection of the MBLs production was performed using the KPC/MBL Confirmation kit (ROSCO ${ }^{\circledR}$ ) and the MBL Etest ${ }^{\circledR} I P / I P I$ (BioMérieux). We used the PCR method for detecting MBLs encoding genes: blaIMP, blaVIM.

Results: The strains were obtained from surgery (55.3\%), ICU (15.8\%) and gastroenterology wards (28.9\%), isolated from pus (25.8\%), tracheal secretion (22.7\%), bile (13.6\%), sputum (10.6\%), blood (10.6\%), other secretions (16.7\%). These strains were resistant to multiple classes of antibiotics. By ROSCO ${ }^{\circledR}$ method 28/38 strains (73.7\%) were positive with imipenem \pm dipicolinic acid (DPA) and 22/38 (57.9\%) with meropenem \pm DPA. Etest ${ }^{\circledR}$ was
\end{abstract}

\footnotetext{
* Corresponding author: Luminița Matroș, University of Medicine and Pharmacy „Iuliu Hatieganu”, Microbiology
} Department, no.6, Pasteur, Cluj-Napoca, Romania, e-mail: lumi_matros@yahoo.com 
positive for the $28 / 38$ strains (73.7\%). 11 strains (28.9\%) were positive for KPC with the screening method. We identified: 6 blaIMP+ (15.8\%), 2 (5.3\%) blaVIM+ and 4 blaIMP+/blaVIM+ strains (10.5\%).

Conclusion: Both genes encoding MBL were found, alone or in combination. The increasing level of carbapenem resistance of these strains impose their routine testing to detect $M B L$.

Keywords: double-disk synergy; E-test; metallo- $\beta$-lactamase; PCR; Pseudomonas aeruginosa.

\section{Rezumat}

Introducere: Infecţiile nosocomiale determinate de tulpinile de Pseudomonas aeruginosa producătoare de carbapenemaze reprezintă o importantă cauză de morbiditate şi mortalitate la pacienţii imunosupresaţi. Acest studiu și-a propus să detecteze prin metode fenotipice de screening producerea de metalo- $\beta$-lactamaze (MBL) şi să detecteze genele cele mai frecvente, răspunzătoare de secreția lor (genele blaIMP şi blaVIM) prin metoda PCR la tulpini de P. aeruginosa izolate la pacienţi spitalizaţi în Institutul Regional de Gastroenterologie şi Hepatologie din Cluj-Napoca. Material şi metodă: În perioada septembrie 2014-februarie 2015, au fost testate 38 de tulpini de P. aeruginosa rezistente la carbapenemi, interpretate cu sistemul Vitek ${ }^{\circledR}$ Compact (BioMérieux) conform CLSI 2014, izolate din produse patologice diverse. Detecţia fenotipică a MBL s-a realizat cu ajutorul kit-urilor KPC/MBL Confirmation kit $\left(\right.$ ROSCO $\left.^{\circledR}\right)$ şi MBL Etest ${ }^{\mathbb{I}}$ IP/IPI (BioMérieux). Pentru detecția genelor blaIMP, blaVIM s-a utilizat metoda PCR, folosind primeri specifici.

Rezultate: Tulpinile testate au provenit din secţiile de chirurgie (55.3\%), terapie intensivă (15.8\%) şi gastroenterologie (28.9\%), fiind izolate din: puroi (25.8\%), secreţii traheale (22.7\%), bilă (13.6\%), spută (10.6\%), hemoculturi (10.6\%), alte secreţii (16.7\%). Aceste tulpini au prezentat un profil de rezistenţă multiplă la antibiotice. Prin metoda ROSCO ${ }^{\circledR}, 28 / 38$ de tulpini (73.7\%) au fost pozitive, observându-se sinergie între imipenem şi dipicolinic acid (DPA), iar la 22/38 (57.9\%) s-a observat sinergie intre meropenem şi DPA. 11 tulpini (28.9\%) au fost pozitive pentru KPC prin metoda screening. Testul MBL Etest ${ }^{\circledR} I P / I P I$ a detectat $28 / 38$ tulpini $M B L+(73.7 \%)$. Au fost identificate prin PCR: 6 tulpini blaIMP+ (15.8\%), 2 blaVIM+ (5.3\%) şi 4 blaIMP+/blaVIM+ (10.5\%).

Concluzii: Au fost identificate ambele gene blaIMP și blaVIM atât singure cât şi în combinaţie. Creșterea prevalenței infecțiilor determinate de tulpinile rezistente la carbapenemi impune testarea lor de rutină pentru detecţia $M B L$.

Cuvinte cheie: dublu-disc sinergie; E-test; metalo-beta-lactamaza; PCR; Pseudomonas aeruginosa.

Received: $7^{\text {th }}$ October 2015; Accepted: 10 ${ }^{\text {th }}$ May 2016; Published: $31^{\text {th }}$ May 2016.

\section{Introduction}

Nosocomial infections caused by Pseudomonas aeruginosa producing carbapenemases are being reported ever more frequently worldwide, and they represent an important cause of morbidity and mortality among immunosuppressed patients (1-3). Most carbapenem resistance is due to impermeability by the loss of the $O p r D$ porin, but carbapenem-hydrolizing metallo- $\beta$-lactamases (MBLs) are increasingly reported (4). The $\beta$-lactamases are divided into four Ambler molecular classes (A, B, C, D), considering their amino-acid sequences and into 2 functional groups, such as serine $\beta$-lactamases $(\mathrm{A}, \mathrm{C}, \mathrm{D})$ and MBLs (B), according to their catalytic ac- tion. MBLs are metallo-enzymes that use bivalent metal ions $\left(\mathrm{Zn}^{2+}, \mathrm{Cd}^{2+}\right)$ as co-factors in their catalytic action on the $\beta$-lactam ring of carbapenems (3,5-7). Group A includes penicillinases, extended-spectrum beta-lactamases (ESBL) and class A carbapenemases. Klebsiella pneumoniae carbapenemases (KPCs) belongs to this group, which hydrolyze penicillins, cephalosporins and carbapenems. These enzymes are inhibited or partially inhibited by clavulanate or tazobactam (5). KPC-producing $P$. aeruginosa isolates were first reported in 2006 from Colombia and subsequently in Puerto Rico, in Trinidad and Tobago, in the southern part of the United States, and in China (8). Group C includes $A m p C$ cephalosporinases, which exhibits a greater hydrolysis 
for cephalosporins in comparison to benzylpenicillin $(5,6)$. Group D includes oxacillinases (OXAs), enzymes able to hydrolyze cloxacillin or oxacillin. Some of them can hydrolyse carbapenems, such as OXA-48 or OXA-23 $(5,9)$. MBLs are the most important carbapenemases class both due to their ability to hydrolyse all $\beta$-lactams drugs, with the exception of monobactams $(3,4)$, and also due to their resistance to inhibitors (10). At present, group B of MBLs are divided into three subclasses (B1, B2 and B3) (11). The most common MBLs reported worldwide belong to the subclass B1, being represented by different families: IMP, VIM, SPM, SIM, GIM, NDM, DIM (11). The most prevalent families of MBLs are the IMP and VIM enzymes; 53 IMP subtypes and 46 VIM variants are known, grouped into 3 clusters (11-13). IMP-type MBL determinants are mostly found in P. aeruginosa, Acinetobacter baumannii and Enterobacteriaceae strains (12). VIM enzymes are prevalent in Europe, although they are currently widespread on all 5 continents, especially VIM-2 (14). VIM-2 has been shown to be associated with a gene cassette, which encodes enzymes that inactivate aminoglycosides (15).

In 2014, the level of carbapenem resistance in $P$. aeruginosa strains isolated from our hospital reached an average value of $66.9 \%$, which led us to initiate this study for MBLs detection.

The aim of the present study was to detect the production of carbapenemases in $P$. aeruginosa strains by phenotypic methods (double disk synergy test, E-test) and the presence of the most common MBLs encoding genes $\left(b l a_{\mathrm{VIM}} b l a_{\mathrm{IMP}}\right)$ by polymerization chain reaction (PCR).

\section{Materials and methods}

We conducted a prospective study between September 2014 - February 2015 in the micro- biology department of the Regional Institute of Gastroenterology and Hepatology (RIGH), Cluj-Napoca, Romania. In this study, a total of 38 non-repeat $P$. aeruginosa strains, with resistance to carbapenems isolated from the hospitalized patients during this period, were included. We obtained the agreement of the Ethics Committee for this study.

The $P$. aeruginosa strains were identified using the VITEK $^{\circledR} 2$ GN card (BioMérieux, Marcy-l'Étoile, France).

Antibacterial susceptibility testing was performed with the VITEK ${ }^{\circledR} 2$ Compact automated system using N222 and XN05 cards. The results were interpreted according to Clinical and Laboratory Standards Institute 2014 (CLSI) breakpoints (16). The resistance phenotypes were also analyzed by VITEK ${ }^{\circledR} 2$ Compact system. Internal quality control was performed with the control strains: P. aeruginosa ATCC 27853, Escherichia coli ATCC 25922, E. coli ATCC 35218 and $K$. pneumoniae ATCC 700603.

Further studies were performed on all 38 non-susceptible of $P$. aeruginosa strains to carbapenems (MICimipenem $\geq 16 \mu \mathrm{g}$ / $\mathrm{ml}$, MICmeropenem $\geq 16 \mu \mathrm{g} / \mathrm{ml})$. The carbapenemase production was confirmed by plating the strains on chromID ${ }^{\circledR}$ CARBA (BioMérieux, France). For all carbapenemase-producing strains, the antimicrobial susceptibility to aztreonam (ATM) was tested by Kirby-Bauer method with ATM $30 \mu \mathrm{g}$ disk (Oxoid, UK). The interpretation was performed according to CLSI 2014 standards (16).

I. The phenotypic detection of MBLs production was done by:

I.a. double disk synergy test (DDST) using the KPC/MBL in $P$. aeruginosa/Acinetobacter baumannii confirmation kit (ROSCO ${ }^{\circledR}$ Diagnostics, Taastrup, Denmark). An overnight broth culture from the tested strains (turbidity adjust- 
ed to 0.5 McFarland standard) was inoculated on a Mac Conkey agar plate in accordance to the manufacturer's rules. Then, five disks: IMI$10 \mu \mathrm{g}$ (imipenem), MRP-10 $\mu \mathrm{g}$ (meropenem), DPA (dipicolinic acid), MRPBO (meropenem combined with phenylboronic acid - PBO) and MPCXH (meropenem combined with high concentration of cloxacillin - $\mathrm{CXH}$ ) were applied on the agar plate. The plate was incubated at $37^{\circ} \mathrm{C}$ for $18 \pm 2$ hours (overnight) (17). Internal quality control was performed with the control strains: P. aeruginosa ATTC 10145/CCUG 59626, MBL positive and K. pneumoniae CCUG 56233, KPC positive (Table 1).

I.b. MBL E-test (Epsilometer - test) was performed with the Etest ${ }^{\mathbb{B}}$ MBL IP/IPI 256/64 (BioMérieux, Marcy-l'Étoile, France), IP (imipenem) $(4-256 \mu \mathrm{g} / \mathrm{ml}) /$ IPI (imipenem: 1-64 $\mu \mathrm{g} / \mathrm{ml}$
+ ethylenediaminetetraacetic acid -EDTA - at a constant level) (18).

Interpretation: MBL positive: a reduction in the minimum inhibitory concentration (MIC) in the presence of EDTA greater than or equal to eight (IP/IPI $\geq 8$ ); the deformation of the ellipse or the presence of a phantom-zone (18).

II. The genotypic detection of MBL production was done by PCR method for genes: blaIMP, blaVIM.

Fresh cultures were harvested and boiled in buffer TBE (Tris Borat EDTA) for 15 minutes, and briefly centrifuged (13,000 rpm, $2 \mathrm{~min})$. Supernatants were used as PCR templates. The following primers were synthesized (at Eurogentec, Belgium) and used. The selected primers for the genes that codify the MBLs had been chosen as general primers for the IMP and VIM

Table 1. Interpretation of the $\operatorname{ROSCO}^{\circledR}$ method

\begin{tabular}{lcccccc}
\hline & Mac Conkey agar & & MRPBO & MPCXH & DPA & Reference \\
\hline No carbapenemases & P. aeruginosa & MRP 10 & - & $\geq 5 \mathrm{~mm}$. & - & $(17)$ \\
KPC & P. aeruginosa & MRP 10 & $\geq 4 \mathrm{~mm}$. & $<3 \mathrm{~mm}$. & - & $(17)$ \\
& & MPCXH & $\geq 4 \mathrm{~mm}$. & - & - & $(17)$ \\
MBLs & P. aeruginosa & IMI 10 & - & - & synergism & $(17)$ \\
\hline
\end{tabular}

MRP 10 - meropenem dsk; IMI 10 - imipenem disk; MRPBO - meropenem disk combined with phenylboronic acid; MPCXH - meropenem disk combined with cloxacillin high; DPA dipicolinic acid; KPC - Klebsiella pneumoniae carbapenemase; MBLs - metallo- $\beta$-lactamases.

Table 2. PCR primers used for detection of carbapenemase resistance genes in $P$. aeruginosa

\begin{tabular}{llcccc}
\hline Gene & Primers & References & $\begin{array}{c}\text { Product } \\
\text { size }\end{array}$ & $\begin{array}{c}\text { Anneling } \\
\text { temperature }\end{array}$ & Extension \\
\hline BlaIMP-F & 5'- GAA GGC GTT TAT GTT CAT & & $578 \mathrm{bp}$ & $51^{\circ} \mathrm{C}$ & $50 \mathrm{sec}$ \\
& AC - 3' (Eurogentec, Belgium) & & & & \\
BlaIMP-R & 5'- GTA TGT TTC AAG AGT GAT & & & & \\
& GC - 3' (Eurogentec, Belgium) & & & & \\
\hline BlaVIM-F & 5'- GTT TGG TCG CAT ATC GCA & & & & \\
& AC - 3' (Eurogentec, Belgium) & & & & \\
BlaVIM-R & 5'- AAT GCG CAG CAC CAG GAT & & & & \\
& AG - 3' (Eurogentec, Belgium) & & & & \\
\hline
\end{tabular}


genes (19). See table 2. Reactions were carried out using Promega DNA Taq-polymerase, with $1.6 \mathrm{mM} \mathrm{MgCl}_{2}$ on a Seegene ${ }^{\mathrm{TM}}$ thermal cycler with the following protocols: $8 \mathrm{~min}$. initial denaturation at $95^{\circ} \mathrm{C}, 40$ cycles of $30^{\prime \prime} 95^{\circ} \mathrm{C}, 35^{\prime \prime} \mathrm{T}_{\text {ann, }}$ $72^{\circ} \mathrm{C}$ extension; $10 \mathrm{~min}$. final extension at $72^{\circ} \mathrm{C}$. Electrophoresis was carried out on $1.8 \%$ agarose gel. The molecular tests for blaIMPand blaVIM were separately done (mono PCR). The tests were performed in duplicate and the results were similar. We used two strains as internal positive control, one positive for blaIMP, and the other one, positive for blaVIM, confirmed in another center (Table 2).

\section{Statistical analysis}

The analysis of concordance between phenotypic screening methods (ROSCO ${ }^{\circledR}$ and E-test) and PCR, considered the reference method, we applied the Mc'Nemar test, Cohen's Kappa coefficient. Fisher's exact test was used for testing the association between the ATM variable and studied tests $\left(\right.$ ROSCO $^{\circledR}$ and E-test). For all two-sided tests, we considered that statistical significance was achieved when the estimated $p$-value was $<0.05$. Data were analyzed using IBM SPSS Statistics v.20 (Armonk, NY: IBM Corp.).

\section{Results}

The thirty-eight tested strains were isolated from surgery $(\mathrm{n}=21 ; 55.3 \%)$, intensive care unit - ICU $(\mathrm{n}=6 ; 15.8 \%)$, and gastroenterology wards $(\mathrm{n}=11$; $28.9 \%$ ). These strains were isolated from various clinical specimens: pus $(n=9 ; 23.7 \%)$, tracheal secretion $(n=5 ; 13.2 \%)$, bile $(n=7 ; 18.4 \%)$, sputum $(n=6 ; 15.8 \%)$, blood $(n=3 ; 7.9 \%)$, central venous catheters $(n=2 ; 5.3 \%)$, urine $(n=2 ; 5.3 \%)$, nasal secretion $(n=1 ; 2.6 \%)$, stool $(n=1 ; 2.6 \%)$ and other secretions $(\mathrm{n}=2 ; 5.3 \%)$.

The tested $P$. aeruginosa strains had significant resistance to multiple classes of antibiotics (anti-pseudomonal $\beta$-lactams, aminoglycosides, fluoroquinolones). See figure 1. Only one strain (2.6\%) showed resistance to polypeptides (MICcolistin: $4 \mathrm{mg} / \mathrm{l})$. To ATM, 18/38 strains (56.5\%) were susceptible, $8 / 38$ intermediate $(21.1 \%)$, and $12 / 38(31.6 \%)$ were resistant. All these strains grew on chromID ${ }^{\circledR}$ CARBA (Figure 1).

The phenotypic detection of carbapenemases production:

I.a. Phenotypic detection of $M B L$ with the ROSCO ${ }^{\circledR}$ method: The synergy area was observed between IMI \pm DPA disks in twenty-eight strains $(73.7 \%)$, ten strains $(26.3 \%)$ were MBL negative. For MRP, the synergy area was obvious in twenty-two strains $(57.9 \%)$ and absent in sixteen strains $(42.1 \%)$. Eleven strains were positive for KPC (28.9\%), twenty-seven strains were negative for $\mathrm{KPC}(71.1 \%)$.

I.b. MBL IP/IPI E-test: Twenty-eight strains (73.7\%) were $\mathrm{MBL}+$ for a ratio IP/IPI $\geq 8$ and the rest were negative.

II. Genotypic detection of genes encoding MBLs (blaIMP, blaVIM) by PCR method: 12 strains out of 38 tested strains $(34,2 \%)$ carried one or both genes - $6(15.8 \%)$ strains were bla IMP+, $2(5.3 \%)$ strains were blaVIM+ and 4 (10.5\%) strains were blaIMP+/blaVIM+. Two blaIMP+ and one blaVIM+ strains were isolated from ICU, 2 blaIMP+, one blaVIM+ and 2 blaIMP+/blaVIM+ strains were isolated from surgery. Two blaIMP+, one blaVIM+ strain and one blaIMP+/blaVIM+ were isolated from gastroenterology wards.

The blaIMP+ strains were isolated from sputum, tracheal secretion, nasal secretion, pus, blood, and central venous catheters, the blaVIM+ strains from urine and sputum, and the blaIMP+/blaVIM+ strains from tracheal secretion, pus and other secretions. These pathological specimens were related to several medical devices (intravenous or urinary catheters, tubes, cannulae, assisted ventilation appliances), on which $P$. aeruginosa has the ability to attach and multiply, forming an impossible to remove bio-film. 


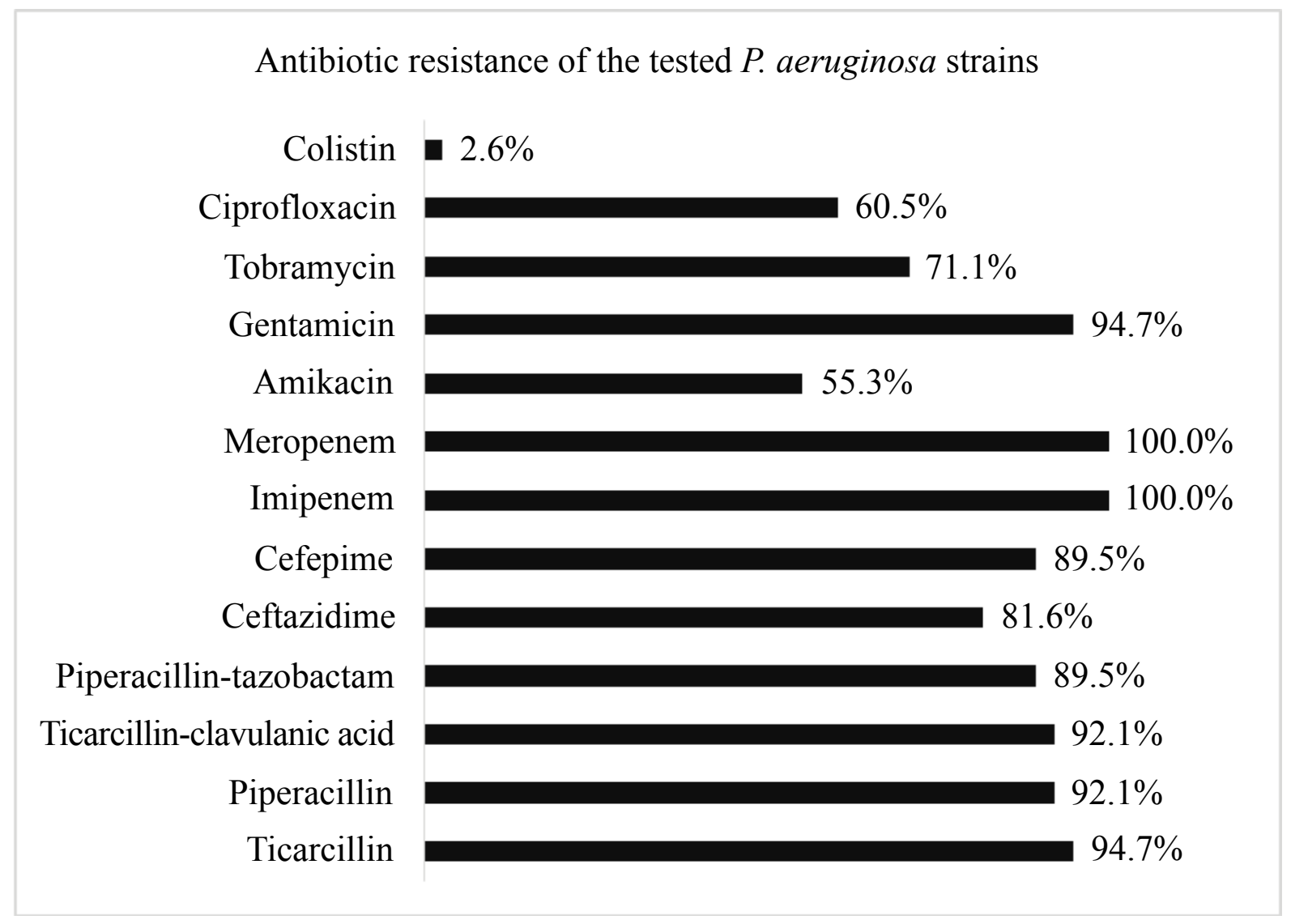

Figure 1. Antimicrobial resistance of the carbapenems-resistant $P$. aeruginosa strains

These strains showed a very high level of resistance to all anti-pseudomonal $\beta$-lactams. All the blaIMP and blaVIM positive strains (12/38) were resistant to ticarcillin (TIC), ticarcillin combined with clavulanat (TIM), piperacillin (PIP) and piperacillin combined with tazobactam (TPZ), ceftazidime (CAZ) and cefepime (FEP). (Table 3).

Regarding the association between the two phenotypic tests, there was concordance between their results. The proportion of positive and negative results of the ROSCO ${ }^{\circledR}$ method was similar to those of the E-test method for the strains with positive PCR (Mc'Nemar test, $p=0.625$ ) and for those with negative PCR (Mc'Nemar test, $p=0.754$ ).
Susceptibilities to ATM were similar for strains with positive and negative ROSCO test (50\% vs $40 \%$ at the sensitive strains, $21.4 \%$ vs $20 \%$ at the intermediate strains or $28.6 \%$ vs $40 \%$ at the resistant strains) and E-test $(17.9 \%$ vs $40 \%$ at the sensitive strains, $17.9 \%$ vs $20 \%$ at the intermediate strains or $64.3 \%$ vs $40 \%$ at the resistant strains) (Fisher's exact test, $p=0.888$ ).

\section{Discussions}

P. aeruginosa is one of the main opportunistic pathogens in the hospital environment. By its important intrinsic resistance to many antibacterials and by its great adaptability and ability to acquire many resistance mechanisms, 
Table 3. Antibiotic resistance profile of the $P$. aeruginosa strains tested by PCR

\begin{tabular}{|c|c|c|c|}
\hline Test PCR & MBLs genes & Antibiotic resistance profile & $\begin{array}{l}\text { Number of } \\
\text { strains }\end{array}$ \\
\hline \multirow[t]{10}{*}{ Positive } & \multirow{5}{*}{ blaIMP+ } & R: TIC, TIM, PIP,TPZ, CAZ, FEP, ATM, GEN & 2 \\
\hline & & R: TIC, TIM, PIP,TPZ, CAZ, FEP, ATM, GEN, TOB & 1 \\
\hline & & R: TIC, TIM, PIP, TPZ, CAZ, FEP, ATM, GEN, TOB, CIP & 2 \\
\hline & & R: TIM, PIP, FEP, ATM, LVX & 1 \\
\hline & & Total & 6 \\
\hline & \multirow[t]{2}{*}{ blaVIM+ } & R: TIC, TIM, PIP,TPZ, CAZ, FEP, ATM, GEN, TOB, AK, CIP & 2 \\
\hline & & Total & 2 \\
\hline & \multirow{3}{*}{$\begin{array}{l}\text { bla IMP+/ } \\
\text { bla } \mathrm{VIM}+\end{array}$} & $\begin{array}{l}\text { R: TIC, TIM, PIP,TPZ, CAZ, FEP, ATM, GEN, TOB, AK, } \\
\text { CIP }\end{array}$ & 3 \\
\hline & & R: TIM, PIP, FEP, ATM, LVX & 1 \\
\hline & & Total & 4 \\
\hline \multirow[t]{9}{*}{ Negative } & \multirow{9}{*}{$\begin{array}{l}\text { blaIMP-/ } \\
\text { blaVIM- }\end{array}$} & R: TIC, TIM, PIP,TPZ, CAZ, FEP, GEN, TOB & 9 \\
\hline & & R: TIC, TIM, PIP,TPZ, CAZ, FEP, GEN, TOB, CIP & 5 \\
\hline & & R: TIC, TIM, PIP,TPZ, CAZ, FEP, GEN, TOB, AK & 1 \\
\hline & & R: TIC, TIM, PIP,TPZ, CAZ, FEP, GEN, TOB, AK, CIP & 5 \\
\hline & & R: TIC, TIM, PIP,TPZ, FEP, GEN, TOB, AK, CIP & 1 \\
\hline & & R: TIM, PIP, FEP & 1 \\
\hline & & R: TIM, PIP, FEP, LVX & 3 \\
\hline & & R: TIM, PIP, FEP, LVX, CT & 1 \\
\hline & & Total & 26 \\
\hline
\end{tabular}

TIC - ticarcillin; TIM - ticarcillin combined with clavulanat; PIP - piperacillin; TPZ - piperacillin combined with tazobactam; CAZ - ceftazidime; FEP - cefepime; ATM - aztreonam; GEN - gentamicin; TOB - tobramycin; AK - amikacin; CIP - ciprofloxacin; LVX - levofloxacin; CT - colistin.

P. aeruginosa became a fearsome bacterium, called deadly superbug, for which the treatment options are extremely limited. The blaIMP and blaVIM negative strains which were resistant to TIC, TIM, PIP, TPZ, CAZ, FEP could suffer structural modifications of $A m p C$ gene (20) or could be carriers for mobile genetic elements (plasmids, integrons) that encode other types of MBLs or OXAs (21). In a study performed in Spanish hospitals in 2008, Cabot et al. showed a correlation of $24.2 \%$ between the resistance to IMI, MRP, CAZ, FEP, TPZ and the AmpC overexpression among $P$. aeruginosa strains isolat- ed from bloodstream infections (22). One strain $\mathrm{PCR} / \mathrm{ROSCO}^{\circledR} / \mathrm{E}$-test negative which was susceptible to CAZ, but resistant to TIC, TIM, TPZ, FEP could suffer a mutation that causes MexEF-OprN hyperproduction combined with $O p r D$ downregulation, a mechanism more rarely seen, which primarily affects fluoroquinolones (20). MBLs hydrolyse all $\beta$-lactams, except monobactams, whose representative is ATM (23). ATM is considered 2nd therapeutic option (after colistin) (23) among active agents against MBLs+ $P$. aeruginosa strains. All the blaIMP + and blaVIM+ strains were susceptible to ATM. We 
have not found significant statistical association between sensitivity to ATM and the ROSCO $^{\circledR}$ method. Likewise we have not found significant statistical association between sensitivity to ATM and the E-test. This could be explained by the existence of other MBLs (unexplored by us), or association with other mechanisms: production of ESBL or KPCs (23), hyper-production of a chromosomal $A m p C$ (4), or the synthesis of carbapenemases class D (OXA-23, OXA-24, OXA-58, OXA-48, OXA-181) (21). In our study, the blaIMP+ strains were sensitive to amikacin, resistant to gentamicin and had variable sensitivity to tobramycin while all the bla VIM+ strains were resistant to aminoglycosides. It is known that the blaVIM gene is associated to class 1 integrons with one or more genes for resistance to aminoglycosides, being able to inactivate antipseudomonal aminoglycosides (gentamicin, tobramycin, amikacin) (24). All the blaVIM+ strains were resistant to ciprofloxacin while 2 out of 4 bla IMP+ strains were susceptible to ciprofloxacin. It could be explained by presence of multiple mechanisms of resistance, such as the MBL synthesis associated with the expression of efflux pumps MexAB-OprM or MexXY, responsible for associated resistance to fluoroquinolones (20). It is possible that a strain produces more types of carbapenemases. We have detected four positive strains for blaIMP and blaVIM genes. M. Wang et al. reported a strain of $P$. aerugino$s a$ producing multiple carbapenemases: NDM-1, VIM-5, VIM-6 (25).

There were important differences between the molecular and phenotypic tests. These could be explained by the secretion of other MBLs, which were not tested in our study. Several Romanian studies regarding MBLs in $P$. aeruginosa strains were made in the last years. In a study conducted in Cluj-Napoca, between 2008-2009, Craciunas et al have not detected blaIMP and blaVIM genes in $P$. aeruginosa strains but OXA-50 and OXA-2 genes, responsible for multidrug resistance of tested strains, were detected (28). The first report of blaVIM gene in the eastern part of Romania was made between 2007-2011, by Mereuta et al. Of the tested strains, $41.5 \%$ were secreting VIM enzyme but the blaIMP gene was not detected (29). In another study performed in Iasi between 2008-2012 presence of blaVIM-2 gene was confirmed in clinical isolates of $P$. aeruginosa (30). Gheorghe et al. reported the presence of blaVIM-4 gene in isolates recovered from the southern part of Romania in the period between 20112012. In their study, the most frequent genes found in $P$. aeruginosa strains resistant to carbapenems were blaOXA-23, blaGES-like and blaVIM-4 (31).

\section{Conclusions}

This was the first study performed in our hospital regarding testing blaIMP and blaVIM genes to carbapenem-resistant strains of $P$. aeruginosa. 6 bla IMP+, 2 bla VIM+ were detected and 4 strains were secreted both MBLs blaIMP+/blaVIM+ strains. We showed the presence of blaIMP gene in this part of Romania. The phenotypic methods for screening MBLs were useful for diagnosis. In further studies, we intend to investigate a wider field of genes to follow the genetic resistance profile of the circulating $P$. aeruginosa strains in our hospital.
Abbreviations
P. aeruginosa - Pseudomonas aeruginosa
MBLs - Metallo-carbapenemases
ESBL - Extended-spectrum $\beta$-lactamase
OXAs - Oxacillinases
IMP - Imipenemase 


\begin{tabular}{|c|c|}
\hline VIM & - Verona imipenemase \\
\hline NDM & - New Delhi metalo- $\beta$-lactamase \\
\hline SPM & - Sao Paolo imipenemase \\
\hline SIM & - Seul imipenemase \\
\hline GIM & - German imipenemase \\
\hline DIM & - Dutch imipenemase \\
\hline ICU & - Intensive Care Unit \\
\hline DDST & - The double-disk synergy test \\
\hline DPA & - Dipicolinic acid \\
\hline KPCs & $\begin{array}{l}\text { - Klebsiella penumoniae } \\
\text { carbapenemases }\end{array}$ \\
\hline PCR & - Polymerization chain reaction \\
\hline RIGH & $\begin{array}{l}\text { - Regional Institute of Gastro- } \\
\text { enterology and Hepatology }\end{array}$ \\
\hline CLSI & $\begin{array}{l}\text { - Clinical and Laboratory } \\
\text { Standards Institute }\end{array}$ \\
\hline MIC & $\begin{array}{l}\text { - Minimum inhibitory concen- } \\
\text { tration }\end{array}$ \\
\hline IMI-10 $\mu \mathrm{g}$ & - Imipenem \\
\hline 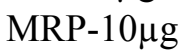 & - Meropenem \\
\hline MRPBO & $\begin{array}{l}\text { - Meropenem combined with } \\
\text { phenylboronic acid }\end{array}$ \\
\hline PBO & - Phenylboronic acid \\
\hline MPCXH & $\begin{array}{l}\text { - Meropenem combined with } \\
\text { high concentration of cloxacillin }\end{array}$ \\
\hline $\mathrm{CX}$ & - Cloxacillin \\
\hline EDTA & - Ethylenediaminetetraacetic acid \\
\hline IP/IPI & - Imipenem/imipenem+EDTA \\
\hline buffer TBE & - Buffer Tris Borat EDTA \\
\hline ATM & - Aztreonam \\
\hline $\mathrm{TIC}$ & - Ticarcillin \\
\hline TIM & $\begin{array}{l}\text { - Ticarcillin combined with } \\
\text { clavulanat }\end{array}$ \\
\hline PIP & - Piperacillin \\
\hline TPZ & $\begin{array}{l}\text { - Piperacillin combined with } \\
\text { tazobactam }\end{array}$ \\
\hline CAZ & - Ceftazidime \\
\hline FEP & - Cefepime \\
\hline $\mathrm{T}_{\mathrm{ann}}$ & - Anneling time \\
\hline CIs & - Confidence intervals \\
\hline GES & $\begin{array}{l}\text { - Guiana extended-spectrum } \\
\beta \text {-lactamase }\end{array}$ \\
\hline
\end{tabular}

\section{Acknowledgements}

This paper was published within the framework of the European Social Fund, Human Resources Development Operational Programme 20072013, project no. POSDRU/159/1.5/S/138776.

Part of this article was presented at $25^{\text {th }} \mathrm{Eu}-$ ropean Congress of Clinical Microbiology and Infectious Diseases - ECCMID, Copenhagen, Denmark, April 25 to 28, 2015.

\section{Conflict of interest}

The authors declare that there are no conflicts of interest.

\section{References:}

1. Deplano A, Denis O, Poirel L, Hocquet D, Nonhoff C, Byl B, et al. Molecular characterization of an epidemic clone of panantibiotic-resistant Pseudomonas aeruginosa. J Clin Microbiol. 2005 Mar;43(3):1198-204. DOI:10.1128/JCM.43.3.1198-1204.2005.

2. Bartolini A, Frasson I, Cavallaro A, Richter SN, Palù G. Comparison of phenotypic methods for the detection of carbapenem non-susceptible Enterobacteriaceae. Gut Pathog. 2014;6:13. DOI:10.1186/1757-4749-6-13.

3. Bertoncheli $\mathrm{C}$ de $\mathrm{M}$, Hörner R. Uma revisão sobre metalo- $\beta$-lactamases. Rev Bras Ciências Farm. 2008 Dec;44(4):577-99. DOI: 10.1590/S151693322008000400005 .

4. Crespo MP, Woodford N, Sinclair A, Kaufmann ME, Turton J, Glover J, et al. Outbreak of carbapenem-resistant Pseudomonas aeruginosa producing VIM-8, a novel metallo-beta-lactamase, in a tertiary care center in Cali, Colombia. J Clin Microbiol. 2004 Nov;42(11):5094101. DOI: 10.1128/JCM.42.11.5094-5101.2004.

5. Hall BG, Barlow M. Revised Ambler classification of $\beta$-lactamases. $\mathrm{J}$ Antimicrob Chemother. 2005;55(6):1050-1. DOI: 10.1093/jac/dki130.

6. Marsik FJ, Nambiar S. Review of Carbapenemases and AmpC-beta lactamases. Pediatr Infect Dis J. 2011;30(12):1094-5. DOI: 10.1097/ INF.0b013e31823c0e47.

7. Meletis G, Exindari M, Vavatsi N, Sofianou D, Diza E. Mechanisms responsible for the emergence of carbapenem resistance in Pseudomonas aeruginosa. Hippokratia. 2012 Oct;16(4):303-7. 
8. Cuzon G, Naas T, Villegas M-V, Correa A, Quinn JP, Nordmann P. Wide dissemination of Pseudomonas aeruginosa producing beta-lactamase blaKPC-2 gene in Colombia. Antimicrob Agents Chemother. 2011 Nov;55(11):5350-3. DOI: 10.1128/AAC.00297-11.

9. Overturf GD, Carbapenemases: A Brief Review for Pediatric Infectious Disease Specialists. 2010 Jan.

10. Hirakata Y, Yamaguchi T, Nakano M, Izumikawa K, Mine M, Aoki S, et al. Clinical and bacteriological characteristics of IMP-type metallo-beta-lactamase-producing Pseudomonas aeruginosa. Clin Infect Dis. 2003 Jul;37(1):26-32. DOI: 10.1086/375594.

11. B-Lactamase Classification and Amino Acid Sequences for TEM, SHV and OXA Extended-Spectrum and Inhibitor Resistant Enzymes. Available from: http:// www.lahey.org/studies/.

12. Buchunde S, Mendiratta DK, Deotale V, Narang P. Comparison of disc and MIC reduction methods with polymerase chain reaction for the detection of metallo- $\beta$-lactamase in Pseudomonas aeruginosa. Indian J Med Microbiol. 2012 Jan;30(2):170-4. DOI: 10.4103/0255-0857.96683.

13. Hansen F, Hammerum AM, Skov R, Haldorsen B, Sundsfjord A, Samuelsen O. Evaluation of the total MBL confirm kit (ROSCO) for detection of metallo- $\beta$-lactamases in Pseudomonas aeruginosa and Acinetobacter baumannii. Diagn Microbiol Infect Dis. 2014 Aug;79(4):4868. DOI: 10.1016/j.diagmicrobio.2013.12.001.

14. Tawfik AF, Shibl AM, Aljohi MA, Altammami MA, Al-Agamy MH. Distribution of Ambler class A, B and D $\beta$-lactamases among Pseudomonas aeruginosa isolates. Burns. 2012 Sep;38(6):855-60. DOI: 10.1016/j. burns.2012.01.005.

15. Cardoso O, Alves AF, Leitão R. Metallo-betalactamase VIM-2 in Pseudomonas aeruginosa isolates from a cystic fibrosis patient. Int J Antimicrob Agents. 2008 Apr;31(4):375-9. DOI: 10.1016/j.ijantimicag.2007.12.006.

16. Clinical and Laboratory Standard Institute. Performance Standards for Antimicrobial Susceptibility Testing; Twenty-Fourth Informational Supplement. CLSI document M100-S24. Clsi. 2014.

17. In FOR, Diagnostic V, Only USE. Rosco Diagnostica. 2013;(98019):1-3.

18. Etest for Antimicrobial Resistance Detection (ARD) | bioMérieux Clinical Diagnostics.
19. Fallah F, Borhan RS, Hashemi A. Detection of bla(IMP) and bla(VIM) metallo- $\beta$-lactamases genes among Pseudomonas aeruginosa strains. Int $\mathrm{J}$ Burns Trauma. 2013 Jan;3(2):122-4.

20. Oliver A, Mulet X, López-Causapé C, Juan C. The increasing threat of Pseudomonas aeruginosa high-risk clones. Drug Resist Updat. Jan;21-22:41-59.

21. Hammoudi D, Ayoub Moubareck C, Karam Sarkis D. How to detect carbapenemase producers? A literature review of phenotypic and molecular methods. J Microbiol Methods. Elsevier B.V.; 2014;107:106-18.

22. Cabot G, Ocampo-Sosa AA, Tubau F, Macia MD, Rodríguez C, Moya B, et al. Overexpression of AmpC and efflux pumps in Pseudomonas aeruginosa isolates from bloodstream infections: prevalence and impact on resistance in a Spanish multicenter study. Antimicrob Agents Chemother. 2011 May;55(5):1906-11. DOI: 10.1128/AAC.01645-10.

23. Franco MRG, Caiaffa-Filho HH, Burattini MN, Rossi F. Metallo-beta-lactamases among imipenem-resistant Pseudomonas aeruginosa in a Brazilian university hospital. Clinics (Sao Paulo). 2010 Jan;65(9):825-9. DOI: 10.1590/S1807-59322010000900002.

24. Zhao W-H, Hu Z-Q. Epidemiology and genetics of VIM-type metallo- $\beta$-lactamases in Gram-negative bacilli. Future Microbiol. Future Medicine Ltd London, UK; 2011 Mar;6(3):317-33.

25. Wang M, Borris L, Aarestrup FM, Hasman $\mathrm{H}$. Identification of a Pseudomonas aeruginosa co-producing NDM-1, VIM-5 and VIM-6 metallo- $\beta$-lactamases in Denmark using whole-genome sequencing. Int J Antimicrob Agents. 2015 Mar;45(3):324-5. DOI: 10.1016/j.ijantimicag.2014.11.004.

26. Khosravi Y, Loke MF, Chua EG, Tay ST, Vadivelu J. Phenotypic detection of metallo- $\beta$-lactamase in imipenem-resistant Pseudomonas aeruginosa. ScientificWorldJournal. 2012 Jan;2012:654939.

27. Dolara P, Arrigucci S, Cassetta MI, Fallani S, Novelli A. Inhibitory activity of diluted wine on bacterial growth: The secret of water purification in antiquity. Int J Antimicrob Agents. 2005;26:338-40. DOI: 10.1016/j. ijantimicag.2005.07.001.

28. Craciunas C, Butiuc-Keul A, Flonta M, Brad A, Sigarteu M. Application of molecular techniques to the study of Pseudomonas aeruginosa clinical isolate in Cluj-Napoca, Romania. Analele Univ. din Oradea Fascicula Biologie. 2010 Jan 1; 17(2):243-247. 
29. Mereuţă AI, Tuchiluş C, Bădescu AC, Iancu LS. Metallo-beta-lactamase-mediated resistance among carbapenem-resistant Pseudomonas aeruginosa clinical isolates. Rev Med Chir Soc Med Nat Iasi. 2011 Jan;115(4):1208-13.

30. Mereuţă AI, Bădescu AC, Dorneanu OS, Iancu LS, Tuchiluş CG. Spread of VIM-2 metallo-beta-lactamase in Pseudomonas aeruginosa and Acinetobacter baumannii clinical isolates from Iaşi, Romania. Rom Rev Lab Med. 2013 Dec;21(4):423-30. DOI: 10.2478/rrlm-2013-0035.
31. Gheorghe I, Czobor I, Chifiriuc MC, Borcan E, Ghiţă C, Banu O, et al. Molecular screening of carbapenemase-producing Gram-negative strains in Romanian intensive care units during a one year survey. J Med Microbiol. Microbiology Society; 2014 Oct;63(Pt 10):1303-10. 